\title{
Effects of hydraulic retention time and bioflocculant addition on membrane fouling in a sponge-submerged membrane bioreactor
}

Lijuan Deng ${ }^{\mathrm{a}}$, Wenshan Guo ${ }^{\mathrm{a}}$, Huu Hao Ngo ${ }^{\mathrm{a}^{*}}$, Bing Du ${ }^{\mathrm{b}}$, Qin Wei ${ }^{\mathrm{c}}$, Ngoc Han Tran ${ }^{\mathrm{d}}$, Nguyen Cong Nguyen ${ }^{\mathrm{e}}$, Shiao Shing Chen ${ }^{\mathrm{e}}$, Jianxin $\mathrm{Li}^{\mathrm{f}}$

${ }^{a}$ Centre for Technology in Water and Wastewater, School of Civil and Environmental Engineering, University of Technology, Sydney, Broadway, NSW 2007, Australia

${ }^{b}$ School of Resources and Environmental Sciences, University of Jinan, Jinan 250022, PR China

${ }^{c}$ Key Laboratory of Chemical Sensing \& Analysis in Universities of Shandong, School of Chemistry and Chemical Engineering, University of Jinan, Jinan 250022, PR China

${ }^{d}$ Department of Civil and Environmental Engineering, Faculty of Engineering, National University of Singapore, 1 Engineering Drive 2, E1A-02-19, Singapore 117576.

${ }^{e}$ Institute of Environmental Engineering and Management, National Taipei University of Technology, No.1, Sec. 3, Chung-Hsiao E. Rd, Taipei 106, Taiwan, ROC

${ }^{f}$ State Key Laboratory of Separation Membranes and Membrane Processes, School of Materials Science and Engineering, Tianjin Polytechnic University, Tianjin 300387, PR China

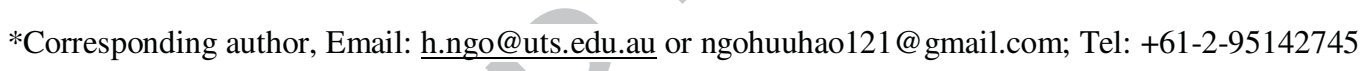

\begin{abstract}
The characteristics of activated sludge and membrane fouling were evaluated in a sponge-submerged membrane bioreactor (SSMBR) at different hydraulic retention times (HRTs) $(6.67,5.33$ and $4.00 \mathrm{~h})$. At shorter HRT, more obvious membrane fouling was caused by exacerbated cake layer formation and aggravated pore blocking.

Activated sludge possessed more extracellular polymeric substances (EPS) due to excessive growth of biomass and lower protein to polysaccharide ratio in soluble microbial products (SMP). The cake layer resistance was aggravated by increased sludge viscosity together with the accumulated EPS and biopolymer clusters (BPC) on membrane surface. However, SMP showed marginal effect on membrane fouling when
\end{abstract}


SSMBRs operated at all HRTs. The SSMBR with Gemfloc ${ }^{\circledR}$ addition at the optimum HRT of $6.67 \mathrm{~h}$ demonstrated superior sludge characteristics such as larger floc size, less SMP in mixed liquor with higher protein/polysaccharide ratio, less SMP and BPC in cake layer, thereby further preventing membrane fouling.

Keywords: Membrane bioreactor; Sponge; Hydraulic retention time; Bioflocculant; Membrane fouling

\section{Introduction}

Although membrane bioreactor (MBR) technology has gained significant popularity for treatment and reuse of municipal, industrial, and landfill wastewaters, its universal appeal is limited by membrane fouling, especially biofouling, with the consequences such as deteriorated membrane filtration performance, reduced lifespan of membrane and increased operating and maintenance costs (Deng et al., 2014; Zhang et al., 2014). One of the key operating parameters having a significant impact on membrane fouling (especially biofouling) during MBR process is hydraulic retention time (HRT), which can alter mixed liquor properties (e.g. extracellular polymeric substances (EPS), soluble microbial substances (SMP) and sludge stability) (Guo et al., 2012). Previous studies have indicated that shorter HRT, resulting in higher organic loading rate (OLR), could increase biomass concentration and sludge viscosity, and decreased dissolved oxygen (DO) concentration. It also induced overgrowth of filamentous bacteria, more EPS production, along with generation of larger, more irregularly and porous sludge flocs. Moreover, the abundance of filamentous bacteria and higher EPS levels facilitated adherence of membrane foulants onto membrane 
surface, and further promoted formation of a thicker cake layer due to bridging action among membrane foulants. In addition, the co-deposition of EPS and sludge flocs onto the membrane surface also gave rise to formation of cake layer and reduced its porosity. Therefore, deteriorated membrane permeability was obtained at shorter HRT (Chae et al., 2006; Meng et al., 2007a).

Current studies have evaluated the performance of conventional MBR (CMBR) when treating various wastewaters at different HRTs. Gao et al. (2012) operated a labscale membrane-based process which consisted of an anoxic tank and an aerobic MBR for digested sewage treatment with decreasing HRTs from 8 to $2.5 \mathrm{~h}$. The results suggested that shorter HRT improved $\mathrm{NH}_{4}-\mathrm{N}$ and T-N removal, but aggravated membrane fouling, increased filtration resistance and fouling rate. The effects of different HRTs (12, 8 and $4 \mathrm{~h}$ ) and sludge retention times (SRTs, 30, 15 and $4 \mathrm{~d}$ ) on the performance of a submerged MBR were investigated by Aida Isma et al. (2015) for synthetic wastewater treatment. They found that longer HRT prompted $\mathrm{PO}_{4}-\mathrm{P}$ removal. At the HRT of $12 \mathrm{~h}$, the MBR with longest SRT of $30 \mathrm{~d}$ achieved better removal efficiencies of COD, $\mathrm{NH}_{4}-\mathrm{N}$ and $\mathrm{PO}_{4}-\mathrm{P}$, while exhibited less membrane fouling with the slowest transmembrane pressure (TMP) increment. Babatsouli et al. (2014) demonstrated an MBR pilot plant with a short SRT of $20 \mathrm{~d}$ for industrial wastewater treatment. At shorter HRT of $19 \mathrm{~h}$, not only lower denitrification and phosphate removal but also higher fouling rate were observed. Although these studies showed HRT plays an important role in MBR performance and membrane fouling, detailed characterisation of activated sludge and cake layer at different HRTs has not been performed. Another study conducted by Qu et al. (2013) examined the effects of long HRTs (i.e. $0.9 \pm 0.1$, 
$1.1 \pm 0.1$, and $1.7 \pm 0.2 \mathrm{~d}$ ) on the performance of a thermophilic submerged aerobic MBR (TSAMBR) for the treatment of thermomechanical pulping pressate. The results indicated that shorter HRT increased EPS contents in bulk sludge and changed cake layer structure through analysing cake layer morphology, but slightly altered EPS contents of cake sludge. However, the variations of activated sludge and cake layer properties during operation at different HRTs were not identified.

Membrane fouling can be controlled through adding biomass carriers (e.g. activated carbon, plastic media and sponge) or flocculants (e.g. inorganic flocculants, organic flocculants and bioflocculants) to modify sludge characteristics. When comparing to other media, sponge has some superior merits, such as lower cost and higher amount of attached-biomass (Guo et al., 2010). The effectiveness of sponge for membrane fouling reduction in MBR has been reported by Deng et al. (2014), indicating that sponge could positively influence mixed liquor properties as well as decrease cake layer and pore blocking. Thanh et al. (2013) also pointed out that lower HRT (higher filtration flux) in sponge MBR led to more severe membrane fouling through monitoring the TMP development. Fouling rate was adversely affected by HRT, following the power equation $\left(\mathrm{dTMP} / \mathrm{dt}=4.2474 \mathrm{HRT}^{-2.225}\right)$. However, systematic analysis and assessment of sludge characteristics and their impacts on fouling in a sponge-submerged MBR (SSMBR) at various HRTs have not been demonstrated yet.

Thus, this study mainly focused on the effects of different HRTs on long-term SSMBR performance (i.e. membrane fouling behaviour, properties of mixed liquor and cake layer) for synthetic wastewater treatment. After determining the optimum HRT, 
the addition of Gemfloc ${ }^{\circledR}$, which has been developed and patented based on the work of Ngo and Guo (2009), for further fouling minimization in a long-term basis was then investigated. For all SSMBR systems, fouling behaviour was evaluated through TMP development, membrane fouling resistance, and characterisation of activated sludge and cake layer including floc size, surface charge, relative hydrophobicity (RH), apparent viscosity, EPS, SMP, and biopolymer clusters (BPC).

\section{Materials and methods}

\subsection{Wastewater}

Synthetic wastewater was prepared using glucose, ammonium sulphate and potassium dihydrogen orthophosphate as the continuous source of biodegradable organic pollutants and nutrient pollutants. The components of synthetic wastewater were identical with those of primarily treated domestic wastewater, providing dissolved organic carbon (DOC) concentration of 330-360 mg/L, chemical oxygen demand (COD) of $100-130 \mathrm{mg} / \mathrm{L}$, ammonium nitrogen $\left(\mathrm{NH}_{4}-\mathrm{N}\right)$ of $12-15 \mathrm{mg} / \mathrm{L}$, and orthophosphate $\left(\mathrm{PO}_{4}-\mathrm{P}\right)$ of $3.3-3.5 \mathrm{mg} / \mathrm{L}$. Adjustment of $\mathrm{pH}$ to 7.0 was accomplished by adding $\mathrm{NaHCO}_{3}$ or $\mathrm{H}_{2} \mathrm{SO}_{4}$ into the SSMBRs.

\subsection{Experimental setup and operating conditions}

Three experimental trials were conducted by operating three lab-scale SSMBRs parallelly at filtration fluxes of 12,15 , and $20 \mathrm{~L} / \mathrm{m}^{2} \cdot \mathrm{h}$, corresponding to HRTs of 6.67 , 5.33, and $4.00 \mathrm{~h}$, respectively. Gemfloc ${ }^{\circledR}$ addition was applied to the SSMBR (denoted as SSMBR-G) with optimum HRT to further mitigate membrane fouling. Each bioreactor had the effective working volume of $8 \mathrm{~L}$ with an immersed polyvinylidene 
fluoride (PVDF) hollow fiber membrane having pore size of $0.2 \mu \mathrm{m}$ and surface area of $0.1 \mathrm{~m}^{2}$. Activated sludge in all SSMBRs was originally seeded from a local Wastewater Treatment Plant, which was subsequently submitted to synthetic wastewater during acclimatization period. When conducting the filtration experiments, SRT was considered infinite (no sludge withdrawal). Each SSMBR was filled with 800 polyesterpolyurethane porous sponge cubes ( $10 \%$ of volume fraction) with the dimensions of 10 $\mathrm{mm} \times 10 \mathrm{~mm} \times 10 \mathrm{~mm}$, density of $28-45 \mathrm{~kg} / \mathrm{m}^{3}$ and cell count of 90 cells/in $(90$ cells per $25.4 \mathrm{~mm}$ ). Prior to the experiments, sponge cubes were acclimatized to synthetic wastewater for 25 days. For the SSMBR-G, $1 \mathrm{~g}$ of Gemfloc $^{\circledR}$ was employed into the bioreactor every day as suggested by our previous study (Deng et al., 2015). The SSMBRs were continuously fed with synthetic wastewater through a feeding pump. The membrane-filtered effluent was obtained using a suction pump connected to the membrane module. The TMP development was recorded by a pressure gauge to monitor membrane fouling propensity in each SSMBR. The initial mixed liquor suspended solids (MLSS) concentrations were 5.06, 5.00, and $5.02 \mathrm{~g} / \mathrm{L}$ in the SSMBRs at HRTs of $6.67,5.33$, and $4.00 \mathrm{~h}$, respectively. MLSS concentration of the SSMBR-G was adjusted to $5.00 \mathrm{~g} / \mathrm{L}$ before the experiment. The SSMBR was installed with a soaker hose air diffuser to supply air at the flow rate of 9-10 L/min, giving the specific aeration demand (SAD) of 5.4-6.0 $\mathrm{m}^{3} / \mathrm{m}^{2}$ (membrane area) $\cdot h$. The dissolved oxygen (DO) concentration in the reactor ranged from 6.5 to $7.5 \mathrm{mg} / \mathrm{L}$. During the operational period, membrane fouling was physically controlled by backwashing at 3 times of the corresponding filtration flux and backwash frequency was two times/day with the duration of $2 \mathrm{~min} / \mathrm{time}$. The membrane modules were cleaned by ex-situ cleaning method when TMP reached 35 
$\mathrm{kPa}$, by using the sequence of $0.5 \%$ citric acid for $6 \mathrm{~h}, 0.4 \%$ sodium hydroxide for $6 \mathrm{~h}$ and $0.8 \%$ sodium hypochlorite for $6 \mathrm{~h}$.

\subsection{Analysis methods}

For influent and effluent samples, the determination of DOC was implemented by a TOC analyzer (Analytikjena Multi N/C 2000). The measurement of COD, MLSS and mixed liquor volatile suspended solids (MLVSS) used the analytical methods shown in Standard Methods (APHA, AWWA, WEF, 1998). Nutrient removal was monitored in terms of $\mathrm{NH}_{4}-\mathrm{N}, \mathrm{NO}_{3}-\mathrm{N}, \mathrm{NO}_{2}-\mathrm{N}$ and $\mathrm{PO}_{4}-\mathrm{P}$ according to photometric method called Spectroquant $^{\circledR}$ Cell Test (NOVA 60, Merck).

To investigate membrane filtration characteristics, the resistance-in-series model was adopted using Darcy's law as the following equation (Choo and Lee, 1996):

$\mathrm{J}=\Delta \mathrm{P} / \mu \mathrm{R}$

$\mathrm{R}_{\mathrm{T}}=\mathrm{R}_{\mathrm{M}}+\mathrm{R}_{\mathrm{C}}+\mathrm{R}_{\mathrm{P}}$

Where $\mathrm{J}$ is the permeate flux; $\Delta \mathrm{P}$ is the TMP; $\mu$ is the viscosity of the permeate; $\mathrm{R}_{\mathrm{T}}$ is total resistance; $\mathrm{R}_{\mathrm{M}}$ is the intrinsic membrane resistance; $\mathrm{R}_{\mathrm{C}}$ is the cake resistance; and $\mathrm{R}_{\mathrm{P}}$ is the pore blocking resistance.

After removing the fouled membrane from the bioreactor at TMP of $35 \mathrm{kPa}$, cake layer collected from the membrane surface by a soft brush was suspended in $100 \mathrm{~mL}$ of distilled water. The protocol for extraction of samples from membrane surface and mixed liquor, and further analyses of their compositions (EPS, SMP and BPC) followed previous studies (Deng et al., 2014; Sun et al., 2008). This study considered proteins 
$\left(\mathrm{EPS}_{\mathrm{P}}, \mathrm{SMP}_{\mathrm{P}}, \mathrm{BPC}_{\mathrm{P}}\right)$ and polysaccharides $\left(\mathrm{EPS}_{\mathrm{C}}, \mathrm{SMP}_{\mathrm{C}}, \mathrm{BPC}_{\mathrm{C}}\right)$ as the major components of the extracted samples, which were quantified by modified Lowry method (Sigma, Australia) and Anthrone-sulfuric acid method, respectively (Raunkjer et al., 1994). In addition, mixed liquor samples were also submitted to the examination of apparent viscosity and surface charge by employing a Brookfield Viscometer M/OO151-E0808 and a Zetasizer Nano ZS (Malvern Instruments, UK), respectively. The relative hydrophobicity $(\mathrm{RH})$ of sludge flocs was measured according to the experimental protocol described in Ji et al. (2010). The morphology and structure of activated sludge samples were recorded using the Olympus System Microscopic Model BX41 (Olympus, Japan), which was conductive to determine the sludge floc size through analysing the microscopic images using Image-Pro Plus software.

\section{Results and discussion}

\subsection{Effects of HRTs on SSMBR performance}

\subsubsection{Overall performance}

The SSMBRs with different HRTs showed good treatment performance in terms of organic removal. The SSMBR at the longest HRT of $6.67 \mathrm{~h}$ exhibited $96.53 \pm 5.36 \%$ of DOC removal, higher than those at HRTs of 5.33 and $4.00 \mathrm{~h}(95.23 \pm 6.89 \%$ and 94.56 $\pm 7.26 \%$, respectively). Shorter HRTs induced a decrease of COD removal efficiencies, with the averages of $95.72 \pm 4.35 \%, 94.29 \pm 4.06 \%$, and $93.75 \pm 3.95 \%$ at HRTs of 6.67 , 5.33, and $4.00 \mathrm{~h}$, respectively. These results suggested that decreased HRT reduced organic matter removal owing to that increased organic loading may impair the biological system for the degradation of organic matters ( $\mathrm{Ng}$ et al., 2014). Nevertheless, at HRTs of $6.67,5.33$ and $4.00 \mathrm{~h}$, the food to microorganism $(\mathrm{F} / \mathrm{M})$ ratios were 0.24 , 
0.28 and $0.33 \mathrm{~kg} \mathrm{BOD} / \mathrm{kg}$ MLVSS. $\mathrm{d}$, respectively, which were within the normal F/M range for activated sludge systems $(0.2$ to $0.5 \mathrm{~kg} \mathrm{BOD} 5 / \mathrm{kg}$ MLVSS $\cdot \mathrm{d})$. Hence, although the shortened HRT increased organic loading rate, organic removal did not reduce significantly.

It was observed that nutrient removals in the SSMBRs were obviously different at various HRTs. The highest $\mathrm{NH}_{4}-\mathrm{N}$ removal of $91.29 \pm 7.43 \%$ was obtained at HRT of $6.67 \mathrm{~h}$, while the removals were lower at HRTs of 5.33 and $4.00 \mathrm{~h}(87.93 \pm 6.23 \%$ and $83.52 \pm 5.76 \%$, respectively). High $\mathrm{NH}_{4}-\mathrm{N}$ removal in these reactors was ascribed to retention of nitrifying bacteria by membrane filtration without sludge withdrawal and higher population of ammonium oxidizing bacteria $(\mathrm{AOB})$ in the reactor caused by the presence of $\mathrm{AOB}$ on the acclimatised sponge during acclimatization period (Chiemchaisri and Yamamoto, 2005; Nguyen et al., 2012). Three SSMBRs achieved more than $80 \%$ of T-N removal, reaching $87.65 \pm 4.63 \%, 83.46 \pm 5.69 \%$ and $80.63 \pm$ $6.41 \%$ at HRTs of $6.67,5.33$ and $4.00 \mathrm{~h}$, respectively. The results revealed the existence of simultaneous nitrification and denitrification (SND) process, which was ascribed to the anoxic condition around the surface of the sponge and inside the sponge due to distinctive DO gradient along the sponge inward depth (Lim et al., 2011). $\mathrm{PO}_{4}-\mathrm{P}$ removal efficiencies in the SSMBRs at HRTs of $6.67,5.33$, and $4.00 \mathrm{~h}$ were $95.23 \pm$ $5.28 \%, 90.36 \pm 6.32 \%$, and $86.78 \pm 4.69 \%$, respectively, suggesting that the presence of anaerobic and anoxic condition at the inner and the outer parts of sponge promoted phosphorus removal (Deng et al., 2014). When decreasing HRT, the higher pollutant loading rates and insufficient retentin time depressed nitrification and denitrification, thereby obtaining lower $\mathrm{NH}_{4}-\mathrm{N}$ and $\mathrm{T}-\mathrm{N}$ removals. Nitrogen was not effectively 
eliminated at shorter HRT, as reflected by effluent $\mathrm{NO}_{3}-\mathrm{N}$ concentrations of $1.80 \pm 0.35$, $5.80 \pm 0.56$ and $8.30 \pm 1.40 \mathrm{mg} / \mathrm{L}$ at HRTs of $6.67,5.33$ and $4.00 \mathrm{~h}$, respectively. Moreover, since phosphorus release could also be inhibited by high concentration of $\mathrm{NO}_{3}-\mathrm{N}, \mathrm{PO}_{4}-\mathrm{P}$ removal declined (Wang et al., 2009; $\mathrm{Ng}$ et al., 2014).

For fouling development, TMP variation at HRT of $6.67 \mathrm{~h}$ was characterized by two step fouling phenomenon i.e., a gentle TMP increase from 2.0 to $8.0 \mathrm{kPa}$ before 73 days, and a subsequently faster TMP increment until it reached $18.5 \mathrm{kPa}$ on day 100 (Fig. 1). The fouling rate was only $0.175 \mathrm{kPa} / \mathrm{d}$ during the entire operational period. At HRTs of 5.33 and $4.00 \mathrm{~h}$, the operating durations of SSMBRs were reduced to 40 days and 27 days before membrane module fouled and TMP reached $35.0 \mathrm{kPa}$, yielding higher fouling rates of 0.825 and $1.204 \mathrm{kPa} / \mathrm{d}$, respectively. These results implied that lower HRT could shorten filtration period, deteriorate filterability, and aggravate membrane fouling. The further interpretation regarding fouling behaviour in SSMBRs is given in Section 3.1.4.

Fig. 1.

\subsubsection{Mixed liquor suspended solids (MLSS), mixed liquor volatile suspended solids (MLVSS) and apparent viscosity}

As SRT was infinite, biomass multiplication was found in SSMBRs. The SSMBR at HRT of $6.67 \mathrm{~h}$ featured a slower MLSS increment, reaching $13.62 \mathrm{~g} / \mathrm{L}$ on day 100, corresponding to the lowest biomass growth rate $(\Delta \mathrm{MLSS} / \Delta \mathrm{t})$ of $0.09 \mathrm{~g} / \mathrm{L} \cdot \mathrm{d}$. On the other hand, rapid sludge accumulation was obtained with final MLSS values of 15.40 $\mathrm{g} / \mathrm{L}$ and $17.24 \mathrm{~g} / \mathrm{L}$ over the operational period when HRT decreased to 5.33 and $4.00 \mathrm{~h}$, 
giving higher biomass growth rates of 0.26 and $0.45 \mathrm{~g} / \mathrm{L} \cdot \mathrm{d}$, respectively. It implied that the reduced HRT increased OLR, which increased biomass growth and MLSS concentration. The average MLVSS/MLSS ratios increased with decreasing HRTs, corresponding to $0.8600,0.8623$, and 0.8639 at HRTs of $6.67,5.33$, and $4.00 \mathrm{~h}$, respectively. When shortening HRT from 6.67 to $5.33 \mathrm{~h}$, sludge viscosity increased from $3.95 \pm 1.75$ to $4.45 \pm 1.96 \mathrm{mPa} \cdot \mathrm{s}$. A further decrease of HRT to $4.00 \mathrm{~h}$ caused a rise of sludge viscosity, obtaining $4.85 \pm 1.65 \mathrm{mPa} \cdot \mathrm{s}$. These results suggested that lower HRT induced significantly higher biomass concentration, resulting in higher sludge viscosity.

\subsubsection{EPS and SMP in mixed liquor}

The variations of total EPS concentrations in activated sludge and SMP concentrations in mixed liquor of three SSMBRs responding to different designated TMPs are displayed in Figs. 2 and 3. Since the development of TMP was less than 20.0 $\mathrm{kPa}(18.5 \mathrm{kPa})$ for $\mathrm{HRT}$ of $6.67 \mathrm{~h}$, EPS levels, $\mathrm{SMP}$ levels and $\mathrm{SMP}_{\mathrm{P}} / \mathrm{SMP}_{\mathrm{C}}$ ratios are presented according to 4 designated TMPs. At HRT of $6.67 \mathrm{~h}$, EPS concentrations were in the range of $9.85-13.27 \mathrm{mg} / \mathrm{L}$, while EPS contents varied remarkably at HRTs of 5.33 $\mathrm{h}(13.77-27.08 \mathrm{mg} / \mathrm{L})$ and $4.00 \mathrm{~h}(20.10-58.68 \mathrm{mg} / \mathrm{L})$. The elevated EPS levels at shorter HRT could be ascribed to the increased OLR $\left(1.19,1.49\right.$ and $1.98 \mathrm{~kg} \mathrm{COD} / \mathrm{m}^{3} \cdot \mathrm{d}$ for HRTs of $6.67,5.33$ and $4.00 \mathrm{~h}$, respectively), which further accelerated biomass growth. Although the highest concentrations of SMP were observed at HRT of $6.67 \mathrm{~h}$ (the maximum value of $7.53 \mathrm{mg} / \mathrm{L})$ compared with those at HRTs of $5.33 \mathrm{~h}(6.06 \mathrm{mg} / \mathrm{L})$ and $4.00 \mathrm{~h}(4.26 \mathrm{mg} / \mathrm{L})$, all SMP values in three SSMBRs were considerably low because significantly less SMP in mixed liquor could be found in MBR with sponge 
addition (Deng et al., 2014). Based on another study of Deng et al. (2015), in a conventional MBR (CMBR) with similar operating conditions (flux of $12 \mathrm{~L} / \mathrm{m}^{2}$, initial biomass of $5 \mathrm{~g} / \mathrm{L}$ and HRT of $6.67 \mathrm{~h}$ ), SMP concentration achieved more than $30 \mathrm{mg} / \mathrm{L}$ when membrane fouling occurred. It should also be noted that a shortened operation time was recorded for the SSMBRs at low HRTs to achieve the maximum TMP allowed $(35.0 \mathrm{kPa})$, i.e. TMP reached $35.0 \mathrm{kPa}$ after 37 and 21 days of operation at HRTs of 5.33 and 4.00 h, respectively (Fig. 1). Hence, higher SMP levels with increased HRT in SSMBR may be due to the accumulation of SMP with evolution of time in the bioreactor. In this case, SMP concentration was not the vital factor to affect membrane fouling.

Fig. 2.

Fig. 3.

\subsubsection{Membrane fouling analysis}

As shown in Fig. 4, fouling resistance distributions in three SSMBRs at different HRTs were measured at the end of each experiment. With decreasing HRT from 6.67 to $5.33 \mathrm{~h}$, total fouling resistance $\left(\mathrm{R}_{\mathrm{T}}\right)$ increased from $2.50 \times 10^{12}$ to $3.20 \times 10^{12} \mathrm{~m}^{-1}$, which further rose to $4.50 \times 10^{12} \mathrm{~m}^{-1}$ at HRT of $4.00 \mathrm{~h}$. Since the same clean membrane resistance $\left(R_{M}\right)$ of $9.00 \times 10^{11} \mathrm{~m}^{-1}$ was obtained for all SSMBRs, the dominant filtration resistance was cake layer resistance $\left(R_{C}\right)$ in this study. The lowest $R_{C}$ was $1.49 \times 10^{12}$ $\mathrm{m}^{-1}$ at HRT of $6.67 \mathrm{~h}$, consisting of $59.60 \%$ of $\mathrm{R}_{\mathrm{T}}$, while $\mathrm{R}_{\mathrm{C}}$ increased to $1.93 \times 10^{12} \mathrm{~m}^{-1}$ and $2.85 \times 10^{12} \mathrm{~m}^{-1}$ at shorter HRTs of 5.33 and $4.00 \mathrm{~h}$, accounting for $60.31 \%$ and $63.33 \%$ of $R_{T}$, respectively. Pore blocking resistance $\left(R_{P}\right)$ followed the similar patterns as that observed for $\mathrm{R}_{\mathrm{C}}$, with the order of $6.67 \mathrm{~h}<5.33 \mathrm{~h}<4.00 \mathrm{~h}\left(1.06 \times 10^{11}, 3.70 \times\right.$ 
$10^{11}$, and $7.50 \times 10^{11} \mathrm{~m}^{-1}$, respectively). These results not only highlighted the importance of cake layer on membrane fouling development, but also suggested that deterioration of membrane permeability at shorter HRTs was caused by more cake layer formation and pore blocking.

\section{Fig. 4.}

For biomass particulates with higher MLSS concentration and sludge viscosity, the net force toward membrane surface can be developed on these particulates as a result of reduced back-transport effects. It can lead to the accumulation of more sludge particles and formation of a sticky cake layer on membrane surface, thereby increasing $R_{C}$ at shorter HRT (Kornboonraksa and Lee, 2009; Meng et al., 2007b). In addition, physical clearance effects of sponge on cake layer, which were dampened by higher sludge viscosity, also gave rise to higher $\mathrm{R}_{\mathrm{C}}$ with decreasing HRT (Deng et al., 2014). Cake layer as the predominant portion of $\mathrm{R}_{\mathrm{T}}$ was characterized by compositions of EPS, SMP, and BPC (Fig. 5). The decline of HRT from 6.67 to $5.33 \mathrm{~h}$ induced a pronounced rise of EPS $_{P}$ and $\mathrm{EPS}_{\mathrm{C}}$ from 2.52 to $8.33 \mathrm{mg} / \mathrm{g}$ cake layer and 1.48 to $5.28 \mathrm{mg} / \mathrm{g}$ cake layer, respectively. Further reduction of HRT from 5.33 to $4.00 \mathrm{~h}$ promoted an increase in EPS levels, obtaining $\mathrm{EPS}_{\mathrm{P}}$ and $\mathrm{EPS}_{\mathrm{C}}$ at 14.40 and $10.10 \mathrm{mg} / \mathrm{g}$ cake layer, respectively. Similarly, the contents of BPC extracted from the membrane surface showed significant variations at different HRTs. The cake layer contained the least $\mathrm{BPC}_{\mathrm{P}}$ and $\mathrm{BPC}_{\mathrm{C}}$ at $\mathrm{HRT}$ of $6.67 \mathrm{~h}$ at 2.42 and $0.95 \mathrm{mg} / \mathrm{g}$ cake layer, respectively. $\mathrm{BPC}_{\mathrm{P}}$ and $\mathrm{BPC}_{\mathrm{C}}$ levels at HRT of $5.33 \mathrm{~h}$ were 2.1 and 7.3 times comparing with those at HRT of $6.67 \mathrm{~h}$, respectively. A dramatic increase of $\mathrm{BPC}_{\mathrm{P}}$ and $\mathrm{BPC}_{\mathrm{C}}$ was observed when HRT decreased to $4.00 \mathrm{~h}$, reaching 2.63 and $30.63 \mathrm{mg} / \mathrm{g}$ cake layer, respectively. These results indicated that 
shorter HRTs increased $R_{C}$ by accumulation of EPS $\left(E_{P S}\right.$ and $\left.E P S_{C}\right)$ and $B P C\left(B P C_{P}\right.$ and $\mathrm{BPC}_{\mathrm{C}}$ ) on membrane surface. However, SMP contents of cake layer in three SSMBRs were substantially low and showed slight changes, with the values of 0.58 , 1.22 and $1.38 \mathrm{mg} / \mathrm{g}$ cake layer at HRTs of $6.67,5.33$ and $4.00 \mathrm{~h}$, respectively. It could be inferred that even the extracted SMP from membrane surface exerted a negligible effect on membrane fouling, which confirmed that SMP were not the key fouling factor under the studied conditions as discussed in Section 3.1.3.

\section{Fig. 5.}

At shorter HRTs, the increased suction force at higher TMP and the increased drag force towards the membrane at higher fluxes induced more readily deposition of larger amounts of bound EPS and BPC on membrane surface to form a biofilm/cake layer (Qu et al., 2013). Moreover, cell lysis and the resulting release of bound EPS could take place at the interior section of the bio-cake layer due to the development of an anoxic and endogenous condition (Hwang et al., 2008). As to mixed liquor, EPS enhanced bacterial adhesion and/or attachment onto the membrane as well as promoted formation of a thick fouling layer on the membrane surface, thereby clogging membrane pores (Tansel et al., 2006; Ng et al., 2006). Therefore, more EPS in activated sludge led to higher $\mathrm{R}_{\mathrm{C}}$ and $\mathrm{R}_{\mathrm{P}}$ at shorter HRTs. At the fourth designated TMP, $\mathrm{SMP}_{\mathrm{P}} / \mathrm{SMP}_{\mathrm{C}}$ ratio declined from 0.81 to 0.45 with decreasing HRT from 6.67 to $5.33 \mathrm{~h}$, which further reduced to 0.16 at the shortest $\mathrm{HRT}$ of $4.00 \mathrm{~h}$ (Fig. 3). As $\mathrm{SMP}_{\mathrm{C}}$ presents partially hydrophilic nature as compared to $\mathrm{SMP}_{\mathrm{P}}$ (Guo et al., 2012), lower $\mathrm{SMP}_{\mathrm{P}} / \mathrm{SMP}_{\mathrm{C}}$ ratio in mixed liquor increased $R_{C}$ and $R_{P}$ at shorter HRTs in terms of higher irremovable fouling, as well as more membrane pore blocking and gel layer formation on membrane surface. 


\subsection{Effects of bioflocculant addition on SSMBR fouling}

Based on the above-mentioned results, HRT of $6.67 \mathrm{~h}$ could be the optimum HRT for SSMBR. Therefore, SSMBR was further investigated through Gemfloc ${ }^{\circledR}$ addition at HRT of $6.67 \mathrm{~h}$.

\subsubsection{The performance of the SSMBR-G and the SSMBR}

As compared to the SSMBR, the removals of DOC and COD increased to $97.76 \pm$ $4.52 \%$ and $96.78 \pm 3.25 \%$ in the SSMBR-G, respectively, indicating the enhancement of organic removal by Gemfloc ${ }^{\circledR}$ application. Although only slightly higher $\mathrm{NH}_{4}-\mathrm{N}$ and $\mathrm{PO}_{4}-\mathrm{P}$ removal efficiencies $(92.96 \pm 5.69 \%$ and $97.45 \pm 4.68 \%$, respectively) were observed, the SSMBR-G presented the improved T-N removal of $91.69 \pm 4.53 \%$, which was consistent with previous findings of the induced denitrification process occurring inside larger sludge flocs (Deng et al,, 2015). Comparing to the SSMBR, a lower biomass growth rate of $0.08 \mathrm{~g} / \mathrm{d}$ was achieved in the SSMBR-G with final MLSS concentration of $13.02 \mathrm{~g} / \mathrm{L}$ over 100 days of operation, which again proved bioflocculant addition could reduce the growth of biomass in bioreactor (Deng et al., 2015; Ngo and Guo, 2009).

TMP variations for 100 days of operation monitored for the SSMBR and the SSMBR-G are depicted in Fig. 6. Higher fouling potential was found in the SSMBR, suggesting that smaller particles aggravated pore blocking and cake layer formation on membrane surface (higher $\mathrm{R}_{\mathrm{P}}$ and $\mathrm{R}_{\mathrm{C}}$ ) (Lim and Bai, 2003). For better comparison of membrane fouling reduction, the TMP development of the CMBR and the CMBR with 
Gemfloc $^{\circledR}$ addition (MBR-G) with similar operating conditions (flux of $12 \mathrm{~L} / \mathrm{m}^{2}$, initial biomass of $5 \mathrm{~g} / \mathrm{L}$ and HRT of $6.67 \mathrm{~h}$ ) are also presented in the small figure in Fig. 6. The SSMBR-G exhibited the least TMP development $(4.0 \mathrm{kPa})$ and fouling rate $(0.035$ $\mathrm{kPa} / \mathrm{d}$ ) throughout 100-day operation, which were about one-fifth of those in the SSMBR. It suggested that a significant improvement in filterability and membrane fouling reduction in the SSMBR-G were achieved by Gemfloc ${ }^{\circledR}$ addition.

\section{Fig. 6.}

\subsubsection{Membrane fouling analysis}

As compared to the SSMBR $\left(2.50 \times 10^{12} \mathrm{~m}^{-1}\right.$ of $\mathrm{R}_{\mathrm{T}}$ and $1.49 \times 10^{12} \mathrm{~m}^{-1}$ of $\left.\mathrm{R}_{\mathrm{C}}\right)$, the SSMBR-G demonstrated lower $\mathrm{R}_{\mathrm{T}}$ and $\mathrm{R}_{\mathrm{C}}$ of $2.07 \times 10^{12} \mathrm{~m}^{-1}$ and $1.10 \times 10^{12} \mathrm{~m}^{-1}$ (53.14\% of $\mathrm{R}_{\mathrm{T}}$ ), respectively. Moreover, a higher $\mathrm{R}_{\mathrm{P}}$ was obtained in the SSMBR (1.06 $\left.\times 10^{11} \mathrm{~m}^{-1}\right)$, almost 2-fold of that in the SSMBR-G $\left(0.70 \times 10^{11} \mathrm{~m}^{-1}\right)$, which accounted for $3.38 \%$ of $\mathrm{R}_{\mathrm{T}}$ in the SSMBR-G. These results highlighted the capability of Gemfloc ${ }^{\circledR}$ in reducing membrane fouling through eliminating pore blocking and decreasing cake layer fouling which was the major fraction of membrane fouling.

Tables 1 and 2 display total concentrations of EPS in activated sludge and SMP in the supernatant of mixed liquor as well as average $\mathrm{EPS}_{\mathrm{P}} / \mathrm{EPS}_{\mathrm{C}}$ and $\mathrm{SMP}_{\mathrm{P}} / \mathrm{SMP}_{\mathrm{C}}$ ratios, which were divided into three Phases, including Phase I (Day 0-26), Phase II (Day 2774), and Phase III (Day 75-100). EPS contents in activated sludge of the SSMBR were also lower (8.80-13.27 mg/L) than those in the SSMBR-G ranging from 13.84 to 20.18 $\mathrm{mg} / \mathrm{L}$ during the operational period. Meanwhile, SMP concentrations in the supernatant of mixed liquor kept relatively stable $(4.95-5.29 \mathrm{mg} / \mathrm{L})$ in Phase I, and then increased slightly and maintained in the range between 5.63 and $5.89 \mathrm{mg} / \mathrm{L}$ within 74 days before 
severe fouling occurred (Phase II). Subsequently, a rapid increase of SMP (6.02-7.53 mg/L) was shown in Phase III, corresponding to the sudden TMP jump. Conversely, activated sludge in the SSMBR-G exhibited lower SMP levels, varying from 2.60 to $5.89 \mathrm{mg} / \mathrm{L}$ during the entire operational period, which could be ascribed to the entrapment of SMP during flocculation process (Dizge et al., 2011). Furthermore, lower $\mathrm{SMP}_{\mathrm{P}} / \mathrm{SMP}_{\mathrm{C}}$ ratios presented for the SSMBR than those for the SSMBR-G $(1.40 \pm 0.81)$ also reflected more severe fouling in SSMBR, as higher SMP concentrations with lower $\mathrm{SMP}_{\mathrm{P}} / \mathrm{SMP}_{\mathrm{C}}$ ratio in activated sludge gave rise to higher $\mathrm{R}_{\mathrm{P}}$ and $\mathrm{R}_{\mathrm{C}}$ (Deng et al., 2015).

\section{Table 1.}

Table 2.

As shown in Table 1, EPS $/ \mathrm{EPS}_{\mathrm{C}}$ ratios were always higher in the SSMBR-G than those in the SSMBR. Generally, EPS P contains amino acids with hydrophobic side groups and possesses positively charged amino groups, while $\mathrm{EPS}_{\mathrm{C}}$ is responsible for hydrophilic nature of activated sludge (Liu et al., 2014). Thus, sludge flocs with higher $\mathrm{EPS}_{\mathrm{P}} / \mathrm{EPS}_{\mathrm{C}}$ ratio have better flocculation ability and surface properties such as zeta potential and RH. It was found that the sludge flocs in the SSMBR-G exhibited larger particle size distribution $(160-340 \mu \mathrm{m})$ than those in the SSMBR $(80-160 \mu \mathrm{m})$, which was due to the increased EPS in the SSMBR-G which induced polymer entanglement and further promoted aggregation of sludge flocs (Yan et al., 2015). Although activated sludge in both MBRs presented similar RH values $(89.43 \pm 5.12 \%$ and $87.57 \pm 9.59 \%$ in the SSMBR-G and the SSMBR, respectively), the zeta potentials of sludge flocs in the SSMBR-G $(1.43 \pm 3.49 \mathrm{mV})$ were more neutral than those in the SSMBR $(-8.16 \pm 4.84$ $\mathrm{mV}$ ) because Gemfloc ${ }^{\circledR}$ addition could improve the surface charge of sludge flocs as well as promote clustering and formation of larger microbial flocs (Lee et al., 2007). 
Through analyzing the cake layer on membrane surface after terminating the experiments, it was found that both MBRs contained similar levels of EPS, with EPS and $\mathrm{EPS}_{\mathrm{C}}$ of 2.46 and $1.32 \mathrm{mg} / \mathrm{g}$ cake layer in the SSMBR-G, respectively. Regarding $\mathrm{SMP}_{\mathrm{P}}$ and $\mathrm{SMP}_{\mathrm{C}}$ of the cake layer, lower values were attained $(0.13$ and $0.12 \mathrm{mg} / \mathrm{g}$ cake layer, respectively) for the SSMBR-G than those for the SSMBR $(0.26$ and $0.32 \mathrm{mg} / \mathrm{g}$ cake layer, respectively). Gemfloc ${ }^{\circledR}$ supplementation in the SSMBR-G also reduced $\mathrm{BPC}_{\mathrm{C}}$ and $\mathrm{BPC}_{\mathrm{P}}$ by $84.8 \%$ and $29.34 \%$, reaching 0.60 and $1.71 \mathrm{mg} / \mathrm{g}$ cake layer, respectively. Thus, Gemfloc ${ }^{\circledR}$ addition could achieve better fouling control and sustain very low TMP development in the SSMBR-G.

\section{Conclusions}

This study examined membrane fouling potential in SSMBRs operated at different HRTs. Increased HRT could alleviate cake layer formation and prevent pore blocking, thereby minimizing membrane fouling. $\mathrm{R}_{\mathrm{P}}$ and $\mathrm{R}_{\mathrm{C}}$ decreased at longer HRT causing by reduced EPS in membrane cake layer and increased $\mathrm{SMP}_{\mathrm{P}} / \mathrm{SMP}_{\mathrm{C}}$ ratio of mixed liquor. For SSMBRs operated at different HRTs, SMP concentration in mixed liquor was not the decisive factor influencing membrane fouling. In addition, further membrane fouling reduction could be achieved in the SSMBR by employing Gemfloc ${ }^{\circledR}$ at the optimum HRT of $6.67 \mathrm{~h}$ through improving the properties of activated sludge and cake layer.

\section{Acknowledgements}

The authors are grateful for the support of the joint University of Technology SydneyChina Scholarship Council (UTS-CSC) Doctor of Philosophy (Ph.D.) Scholarship, as 
well as HYDRA 2002 Research, Development and Consulting Ltd., Hungary for providing the natural starch-based cationic flocculant.

\section{References}

1. Aida Isma, M.I., Idris, A., Omar, R., Razreena, A.R.P., 2015. Effects of SRT and HRT on treatment performance of MBR and membrane fouling. International Journal of Chemical, Molecular, Nuclear, Materials and Metallurgical Engineering 8, 494-498.

2. APHA, AWWA, and WEF, 1998. Standard Methods for the Examination of Water and Wastewater, twentieth ed. American Public Health Association, Washington, DC.

3. Babatsouli, P., Palogos, Ioannis, Michalodimitraki, E., Costa, C., Kalogerakis, N., 2014. Evaluation of a MBR pilot treating industrial wastewater with a high COD/N ratio. J. Chem. Technol. Biotechnol. 90, 26-33.

4. Chae, S.R., Ahna, Y.T., Kang, S.T., Shin, H.S., 2006. Mitigated membrane fouling in a vertical submerged membrane bioreactor (VSMBR). J. Membr. Sci. 280, 572581.

5. Chiemchaisri, C., Yamamoto, K., 2005. Enhancement of oxygen transfer and nitrogen removal in a membrane separation bioreactor for domestic wastewater treatment. Water Sci. Technol. 51, 85-92.

6. Choo, K.H., Lee, C.H., 1996. Membrane fouling mechanisms in the membrane coupled anaerobic bioreactor. Water Res. 30, 1771-1780.

7. Deng, L., Guo, W.S., Ngo, H.H., Zhang, J., Liang, S., Xia, S., Zhang, Z., Li, J., 2014. A comparison study on membrane fouling in a sponge-submerged membrane 
bioreactor and a conventional membrane bioreactor. Bioresour. Technol. 165, 69-74.

8. Deng, L.J., Guo, W.S., Ngo, H.H., Zuthi, M.F.R., Zhang, J., Liang, S., Li, J., Wang, J., Zhang, X., 2015. Membrane fouling reduction and improvement of sludge characteristics by bioflocculant addition in submerged membrane bioreactor. Sep. Purif. Technol. 156, 450-458.

9. Dizge, N., Koseoglu-Imer, D.Y., Karagunduz, A., Keskinler, B., 2011. Effects of cationic polyelectrolyte on filterability and fouling reduction of submerged membrane bioreactor (MBR). J. Membr. Sci. 377, 175-181.

10. Gao, D.W., Tao, Y., An, R., 2012. Digested sewage treatment using membranebased process at different hydraulic retention times. Desalination 286, 187-192.

11. Guo, W., Ngo, H.H., Dharmawan, F., Palmer, C.G., 2010. Roles of polyurethane foam in aerobic moving and fixed bed bioreactors. Bioresour. Technol. 101, 14351439.

12. Guo, W.S., Ngo, H.H., Li, J.X., 2012. A mini-review on membrane fouling. Bioresour. Technol. 122, 27-34.

13. Hwang, B.K., Lee, W.N., Yeon, K.M., Park, P.K., Lee, C.H., Chang, I.S., Drews, A., Kraume, M., 2008. Correlating TMP increases with microbial characteristics in the bio-cake on the membrane surface in a membrane bioreactor. Environ. Sci. Technol. 42, 3963-3968.

14. Ji, J., Qiu, J., Wai, N., Wong, F.S., Li, Y., 2010. Influence of organic and inorganic flocculants on physical-chemical properties of biomass and membrane-fouling rate. Water Res. 44, 1627-1635. 
15. Kornboonraksa, T., Lee, S.H., 2009. Factors affecting the performance of membrane bioreactor for piggery wastewater treatment. Bioresour. Technol. 100, 2926-2932.

16. Lee, W.N., Chang, I.S., Hwang, B.K., Park, P.K., Lee, C.H., Huang, X., 2007. Changes in biofilm architecture with addition of membrane fouling reducer in a membrane bioreactor. Process Biochem. 42, 655-661.

17. Lim, A.L., Bai, R., 2003. Membrane fouling and cleaning in microfiltration of activated sludge wastewater. J. Membr. Sci. 216, 279-290.

18. Lim, J.W., Seng, C.E., Lim, P.E., Ng, S.L., Ahmad Sujari, A.N., 2011. Nitrogen removal in moving bed sequencing batch reactor using polyurethane foam cubes of various sizes as carrier materials. Bioresour. Technol. 102, 9876-9883.

19. Liu, Y., Liu, Z., Wang, F., Chen, Y., Kuschk, P., Wang, X., 2014. Regulation of aerobic granular sludge reformulation after granular sludge broken: Effect of poly aluminum chloride (PAC). Bioresour. Technol. 158, 201-208.

20. Meng, F., Shi, B., Yang, F., Zhang, H., 2007a. Effect of hydraulic retention time on membrane fouling and biomass characteristics in submerged membrane bioreactors. Bioprocess Biosyst. Eng. 30, 359-367.

21. Meng, F.G., Shi, B.Q., Yang, F.L., Zhang, H.M., 2007b. New insights into membrane fouling in submerged membrane bioreactor based on rheology and hydrodynamics concepts. J. Membr. Sci. 302, 87-94.

22. Ng, H.Y., Tan, T.W., Ong, S.L., 2006. Membrane fouling of submerged membrane bioreactors: impact of mean cell residence time and the contributing factors. Environ. Sci. Technol. 40, 2706-2713. 
23. Ng, K.K., Shi, X., Yao, Y., Ng, H.Y., 2014. Bio-entrapped membrane reactor and salt marsh sediment membrane bioreactor for the treatment of pharmaceutical wastewater: treatment performance and microbial communities. Bioresour. Technol. $171,265-273$.

24. Ngo, H.H., Guo, W.S., 2009. Membrane fouling control and enhanced phosphorus removal in an aerated submerged membrane bioreactor using modified green bioflocculant. Bioresour. Technol. 100, 4289-4291.

25. Nguyen, T.T., Ngo, H.H., Guo, W.S., Li, J.X., Listowski, A., 2012. Effects of sludge concentrations and different sponge configurations on the performance of a sponge-submerged membrane bioreactor. Appl. Biochem. Biotechnol. 167, 16781687.

26. Qu, X., Gao, W. J., Han, M.N., Chen, A., Liao, B.Q., 2013. Effect of hydraulic retention time on sludge properties, cake layer structure, and membrane fouling in a thermophilic submerged aerobic membrane bioreactor. Sep. Sci. Technol. 48, $1529-1536$.

27. Raunkjer, K., Hvitved-Jacobsen, T., Nielsen, P.H., 1994. Measurement of pools of protein, carbohydrate and lipid in domestic wastewater. Water Res. 28, 251-262.

28. Sun, F.Y., Wang, X.M., Li, X.Y., 2008. Visualisation and characterisation of biopolymer clusters in a submerged membrane bioreactor. J. Membr. Sci. 325, 691-697.

29. Tansel, B., Sager, J., Garland, J., Xu, S., Levine, L., Bisbee, P., 2006. Deposition of extracellular polymeric substances (EPS) and microtopographical changes on membrane surfaces during intermittent filtration conditions. J. Membr. Sci. 285, $225-231$. 
30. Thanh, B.X., Berg, H., Nguyen, L.N.T., Da, C.T., 2013. Effects of hydraulic retention time on organic and nitrogen removal in a sponge-membrane bioreactor. Environ. Eng. Sci. 30, 194-199.

31. Wang, Y.L., Yu, S.L., Shi, W.X., Bao, R.L., Zhao, Q., Zuo, X.T., 2009.

Comparative performance between intermittently cyclic activated sludgemembrane bioreactor and anoxic/aerobic-membrane bioreactor. Bioresour. Technol. $100,3877-3881$.

32. Yan, L., Liu, Y., Wen, Y., Ren, Y., Hao, G., Zhang, Y., 2015. Role and significance of extracellular polymeric substances from granular sludge for simultaneous removal of organic matter and ammonia nitrogen. Bioresour. Technol. $179,460-466$.

33. Zhang, H., Gao, Z., Zhang, L., Song, L., 2014. Performance enhancement and fouling mitigation by organic flocculant addition in membrane bioreactor at high salt shock. Bioresour. Technol. 164, 34-40. 


\section{Figure captions}

Fig. 1. TMP profile for the SSMBRs at different HRTs.

Fig. 2. Variations of EPS concentrations in activated sludge in the SSMBRs at different HRTs.

Fig. 3. Variations of $\mathrm{SMP}_{\mathrm{P}} / \mathrm{SMP}_{\mathrm{C}}$ ratio and $\mathrm{SMP}$ concentrations in the supernatant in the SSMBRs at different HRTs.

Fig. 4. Fouling resistance distribution in the SSMBRs at different HRTs.

Fig. 5. Compositions of bound EPS, SMP and BPC of cake layer in the SSMBRs at different HRTs.

Fig. 6. TMP profile for the SSMBR, the SSMBR-G, the CMBR and the MBR-G with similar operating conditions (flux of $12 \mathrm{~L} / \mathrm{m}^{2}$, initial biomass of $5 \mathrm{~g} / \mathrm{L}$ and HRT of 6.67 h). 


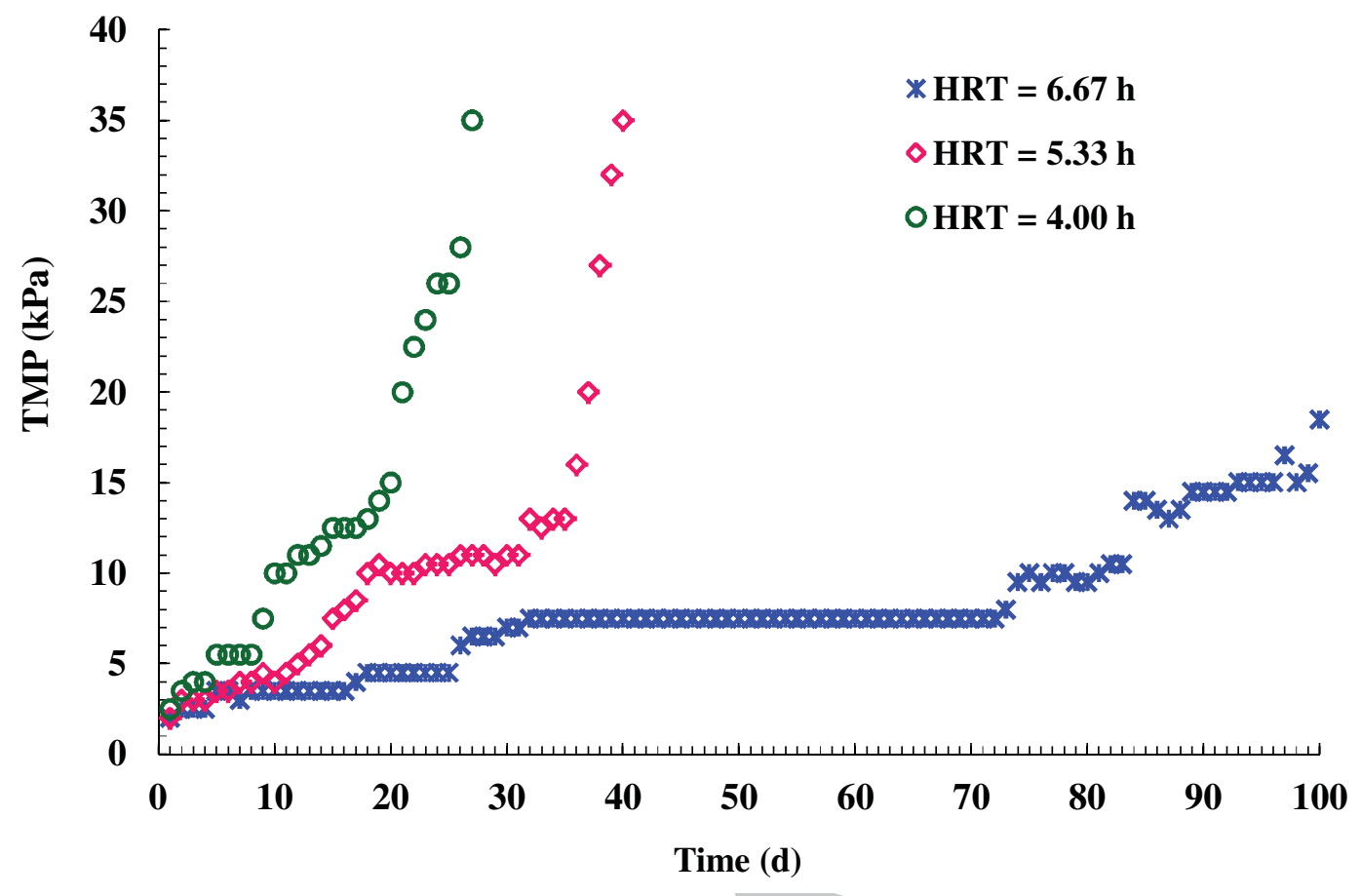

Fig. 1. 


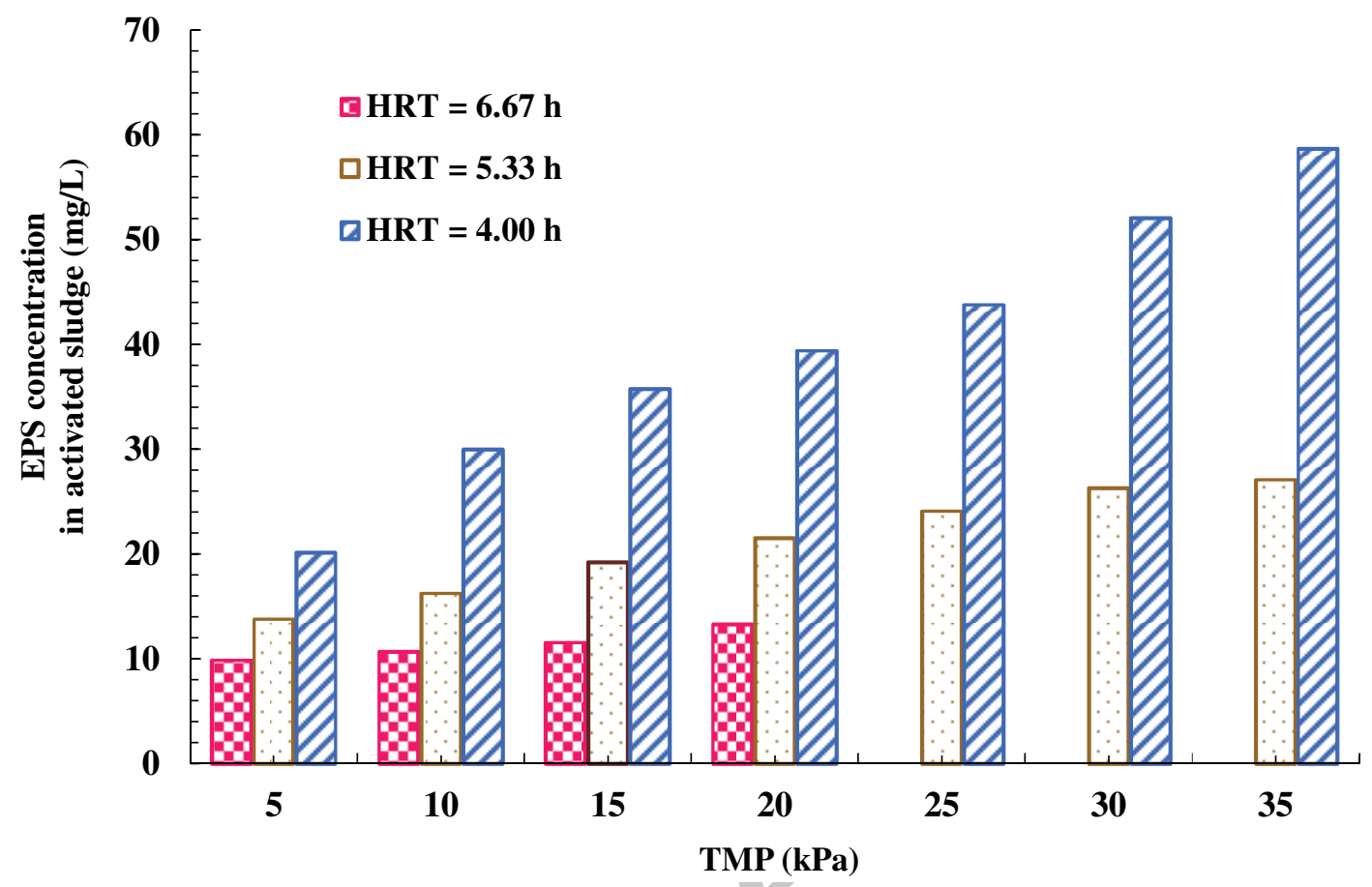

Fig. 2. 


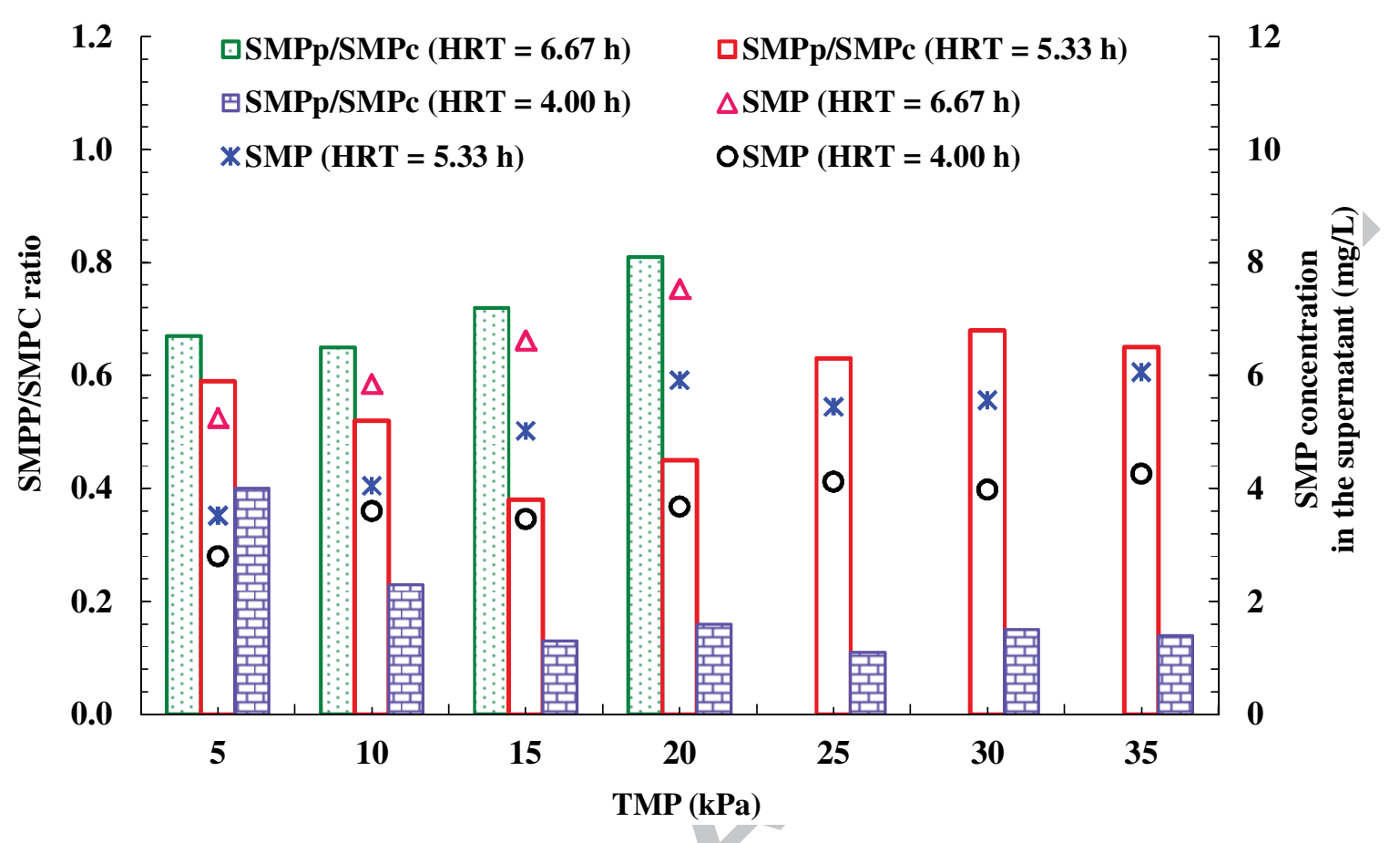

Fig. 3. 


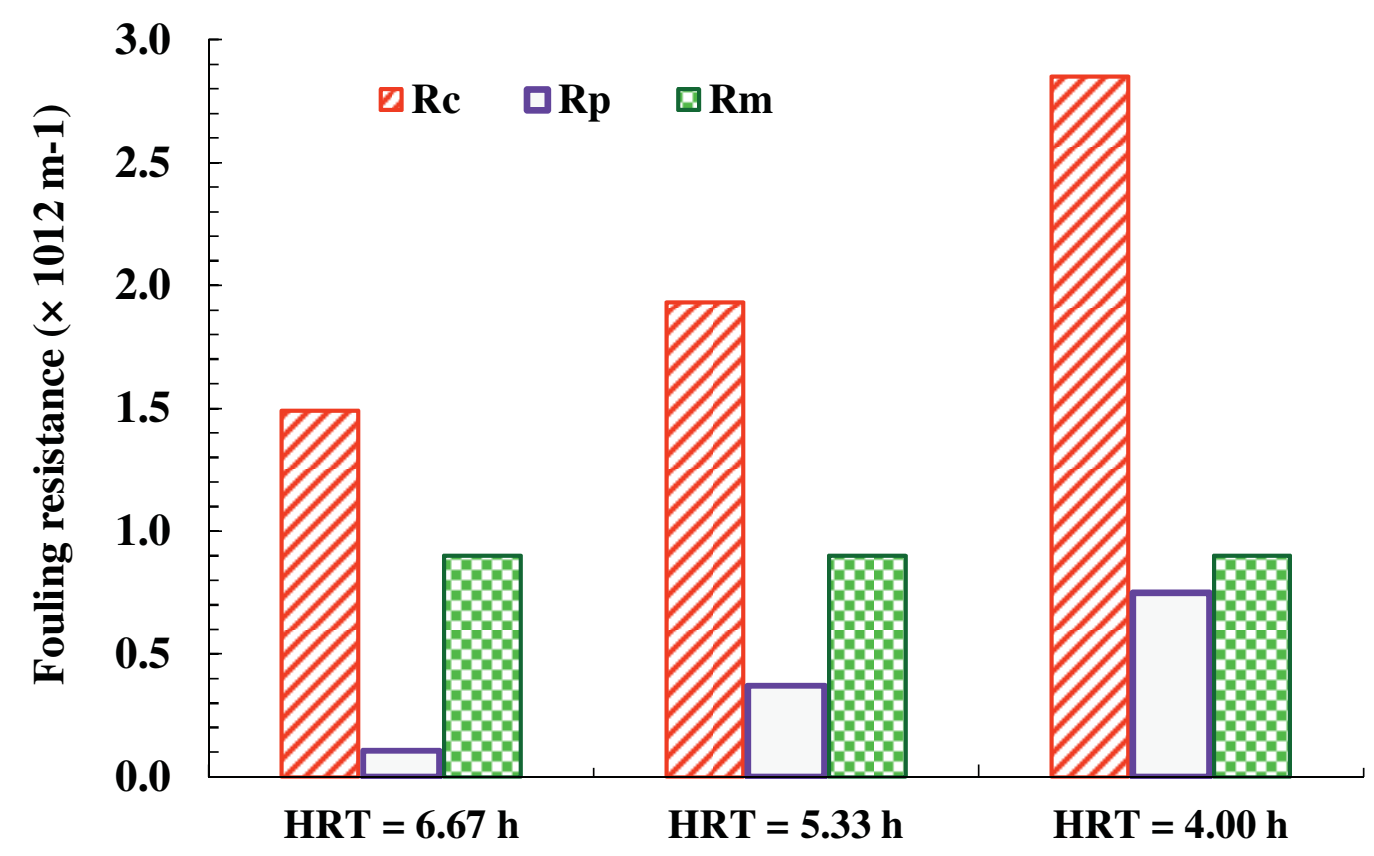

Fig. 4. 


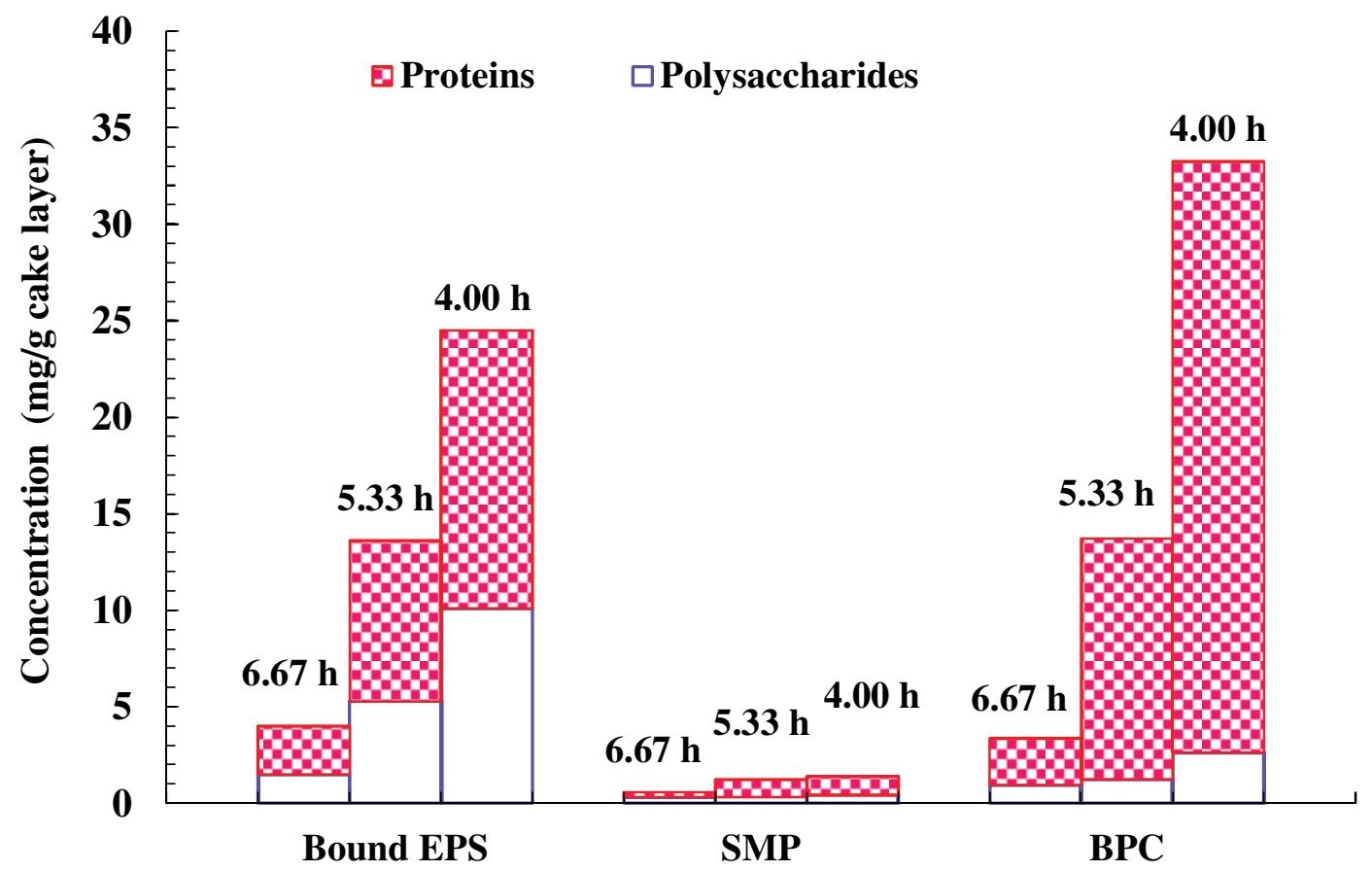

Fig. 5. 


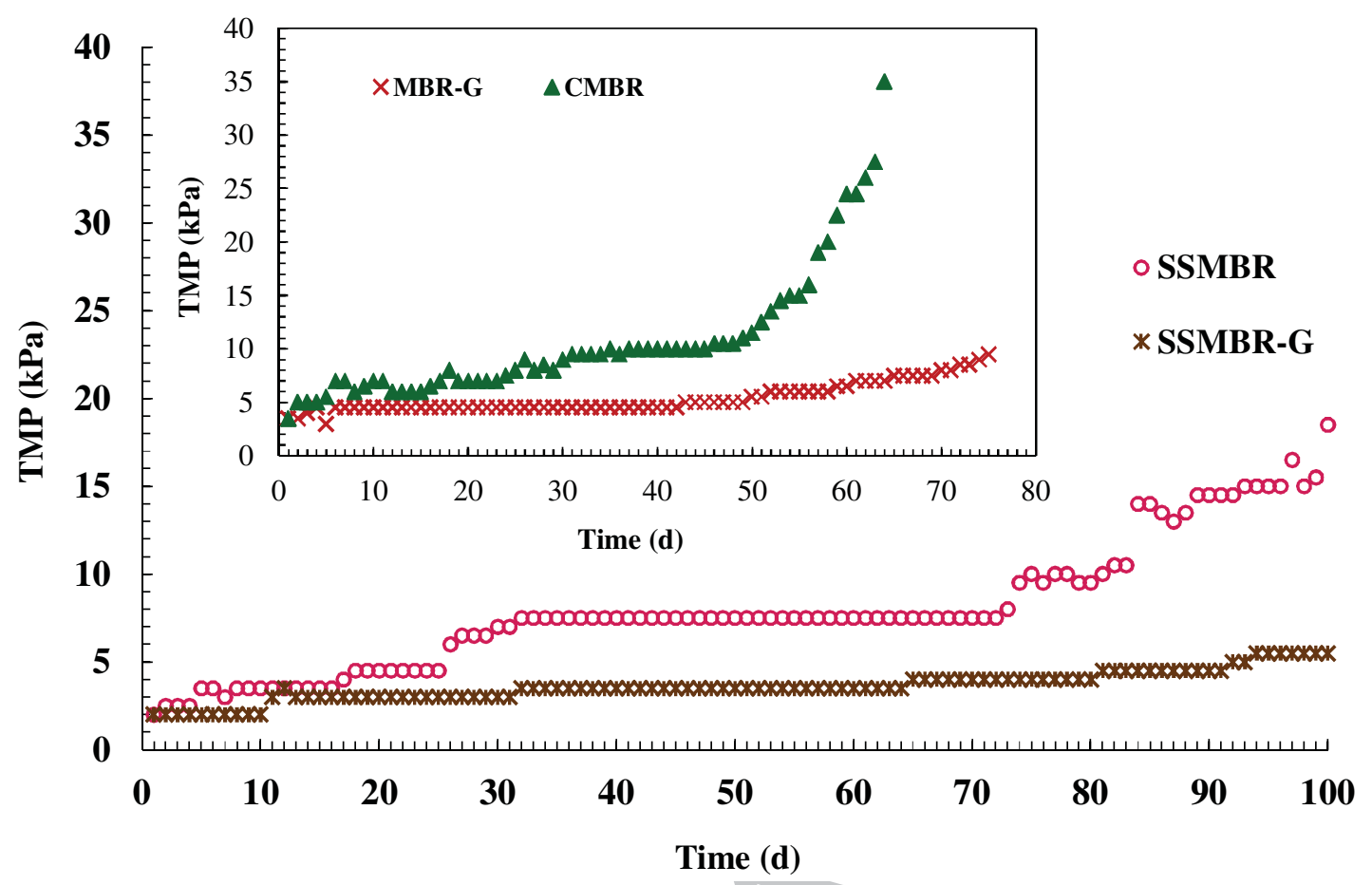

Fig. 6. 


\section{Table titles}

\section{Table 1}

Total EPS concentrations and average $\mathrm{EPS}_{\mathrm{P}} / \mathrm{EPS}_{\mathrm{C}}$ of activated sludge in the SSMBR and the SSMBR-G during the operational period.

\section{Table 2}

Total SMP concentrations and average $\mathrm{SMP}_{\mathrm{P}} / \mathrm{SMP}_{\mathrm{C}}$ of the supernatant of mixed liquor in the SSMBR and the SSMBR-G during the operational period. 


\section{Table 1}

Total EPS concentrations and average EPS $/ \mathrm{EPS}_{\mathrm{C}}$ of activated sludge in the SSMBR and the SSMBR-G during the operational period.

\begin{tabular}{lllll}
\hline \multirow{2}{*}{ Day } & $\begin{array}{l}\text { Phase I } \\
(\text { Day 0-26) }\end{array}$ & $\begin{array}{l}\text { Phase II } \\
\text { (Day 27-74) }\end{array}$ & $\begin{array}{l}\text { Phase III } \\
(\text { Day 75-100) }\end{array}$ \\
\hline \multirow{2}{*}{ EPS (mg/L) } & SSMBR & $8.80-10.20$ & $7.70-10.50$ & $10.26-13.27$ \\
\cline { 2 - 5 } & SSMBR-G & $13.84-20.18$ & $14.01-16.06$ & $13.96-15.42$ \\
\hline \multirow{2}{*}{ EPS $_{\mathrm{P}} / \mathrm{EPS}_{\mathrm{C}}{ }^{\mathrm{a}}$} & SSMBR & $1.48 \pm 0.18$ & $1.35 \pm 0.77$ & $1.27 \pm 0.65$ \\
\cline { 2 - 5 } & SSMBR-G & $1.86 \pm 0.15$ & $2.80 \pm 0.73$ & $2.52 \pm 0.64$ \\
\hline
\end{tabular}

${ }^{\mathrm{a}} \mathrm{EPS}_{\mathrm{P}}$, proteins in EPS; $\mathrm{EPS}_{\mathrm{C}}$, polysaccharides in EPS 
Table 2

Total SMP concentrations and average $\mathrm{SMP}_{\mathrm{P}} / \mathrm{SMP}_{\mathrm{C}}$ of the supernatant of mixed liquor in the SSMBR and the SSMBR-G during the operational period.

\begin{tabular}{lllll}
\hline \multirow{2}{*}{ Day } & $\begin{array}{l}\text { Phase I } \\
(\text { Day 0-26) }\end{array}$ & $\begin{array}{l}\text { Phase II } \\
(\text { Day 27-74) }\end{array}$ & $\begin{array}{l}\text { Phase III } \\
(\text { Day 75-100) }\end{array}$ \\
\hline SMP (mg/L) & SSMBR & $4.95-5.29$ & $5.63-5.89$ & $6.02-7.53$ \\
\cline { 2 - 5 } & SSMBR-G & $3.01-5.89$ & $2.60-3.95$ & $3.25-3.99$ \\
\hline \multirow{2}{*}{ SMP $_{\mathrm{P}} / \mathrm{SMP}_{\mathrm{C}}{ }^{\mathrm{a}}$} & $\mathrm{SSMBR}$ & $0.72 \pm 0.03$ & $0.54 \pm 0.11$ & $0.82 \pm 0.06$ \\
\cline { 2 - 5 } & $\mathrm{SSMBR-G}$ & $1.26 \pm 0.07$ & $1.82 \pm 0.39$ & $1.78 \pm 0.15$ \\
\hline
\end{tabular}

${ }^{\text {a }} \mathrm{SMP}_{\mathrm{P}}$, proteins in $\mathrm{SMP} ; \mathrm{SMP}_{\mathrm{C}}$, polysaccharides in SMP 


\section{Highlights}

- Effects of various HRTs on the SSMBR performance were investigated.

- Shorter HRT aggravated cake layer formation and pore blocking.

- $\quad$ SMP was not the influencing factor to membrane fouling at different HRTs.

- Increased $\mathrm{SMP}_{\mathrm{P}} / \mathrm{SMP}_{\mathrm{C}}$ ratio of mixed liquor resulted in less fouling potency.

- Gemfloc $^{\circledR}$ addition could sustain the performance of SSMBR with minimized fouling. 